\title{
ANALÝZA KVANTITATÍVNYCH UKAZOVATELOV II. PILIERA DÔCHODKOVÉHO SYSTÉMU KRAJÍN V4
}

\author{
Marta Urbaníková, Michaela Štubňová
}

\begin{abstract}
Issues of pension systems regulations are still topical due to the demographic development. Pension systems are an integral part of the social model of all developed countries. The World Bank has proposed to diversify the pension system as a combination of state elements to maintain minimum standards and elements based on private funding and fund management. The aim of the article is quantitative analysis of pension capitalization pillars in the V4 countries. We can state that the highest level of participation in the capitalization pillar is in Poland and the Slovak Republic. For now the contributions to the second pillar as a share of GDP are the highest among the V4 countries in Slovakia. In the Czech Republic, the capitalization pillar was abolished in 2015, and in Hungary $97 \%$ of the savers return to the public pension scheme due to reform in 2010. It can be said that approaches to the capitalization pillar within the V4 countries are significantly different.
\end{abstract}

Keywords: pension system, capitalization pillar, V4 countries, GDP

\section{Úvod}

Úlohou dôchodkového systému je zabezpečit' dostatočný príjem pre občanov v poproduktívnom veku. $V$ rámci celej EÚ v posledných desatročiach prebehli reformy dôchodkových systémov, či už vo forme zmeny doterajšieho dôchodkového systému napr. v krajinách V4, alebo vo forme zmeny niektorých parametrov dôchodkového systému, napr. Francúzko, kde sa zvýšil vek odchodu do dôchodku.

Väčšina verejných dôchodkových systémov V4 garantuje hranicu minimálneho dôchodku, čím by sa malo predchádzat' chudobe po odchode do dôchodku. Takto je zabezpečená minimálna hranica životnej úrovne, pod ktorú by človek nemal klesnút' po odchode na dôchodok. Na grafe 1 je zobrazené percento l'udí vo veku viac ako 65 rokov ohrozených chudobou. Hranica chudoby je určená štátom. Je to relatívna miera, hranica chudoby sa medzi jednotlivými členskými krajinami líši.

Vzhl'adom na demografické zmeny, ako nízka miera pôrodnosti a rast priemernej dížky života, bolo a je treba vykonat' dodatočné reformy s ciel'om zaistit' dlhodobý úspech reforiem a zabezpečit' stabilitu ekonomiky a verejného rozpočtu. 
Graf 1: Ludia vo veku 65 a viac rokov ohrození chudobou Graph 1: People at risk of poverty at the age 65 years or over

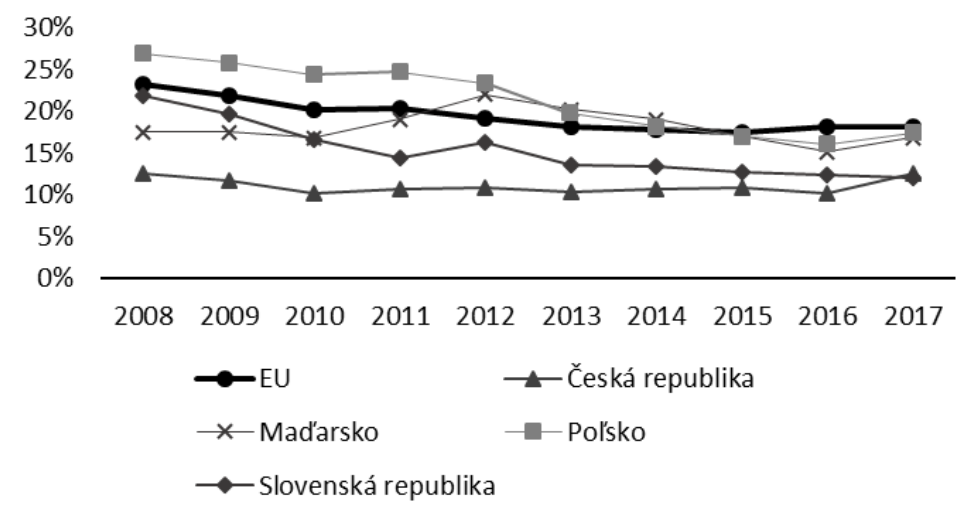

Zdroj: vlastné spracovanie na základe údajov z Eurostat

\section{Teoreticko-metodické východiská}

„Financovanie dôchodkového zabezpečenia je súčast'ou verejných financií a významne ovplyvňuje ich kvalitu a udržatel'nost'. Ked'že dôchodkové systémy určujú životnú úroveň vel'kej časti populácie, a tým aj jej spotrebu, majú rozsiahly dosah na fungovanie celého hospodárstva národného štátu. Samotné dôchodkové systémy sú spätne ovplyvnené ekonomickou stabilitou alebo nevyrovnanost'ou štátu, ovplyvňuje ich zamestnanost', populačný vývoj a d'alšie faktory. Prechádzajú preto neustálym procesom vyrovnávania sa a prispôsobovania hospodárskym, spoločenským aj politickým pomerom v konkrétnom štáte“ (Rievajová, 2013).

\section{Slovenská republika}

V roku 2003 začala rozsiahla reforma slovenského dôchodkového systému, ktorá je plne účinná od januára 2005. Dôchodkový systém SR je trojpilierový a je legislatívne upravený Zákonom č. 43/2004 Z.z. o starobnom dôchodkovom sporení a o zmene a doplnení niektorých zákonov v znení neskorších predpisov.

Prvý pilier dôchodkového sporenia je realizovaný Sociálnou poist'ovňou. Jedná sa o priebežný systém financovania PAYG. Dôchodky v tomto systéme sú vyplácané zo súčasných príspevkov (odvodov) platitel'ov do systému. Príjmy získavané $\mathrm{z}$ tohto verejného a priebežne financovaného systému sociálneho zabezpečenia nie sú akumulované alebo investované, čo robí systém závislým na demografickej situácii a mzdách prispievatel'ov počas určitého obdobia. V priebežnom systéme dôchodky súčasnej dôchodcovskej populácie sú financované pracujúcou čast'ou populácie. 
Druhý pilier je kapitalizačný, už nejde o priebežné financovanie, ale o sporenie si na svoj vlastný dôchodok. Funguje tak, že čast' odvodov sa presmeruje zo Sociálnej poist’ovne priamo do dôchodkových správcovských spoločností. Od 1.1.2005 do 31.8.2012 boli príspevky do DSS vo výške jednej polovice z povinných odvodov na starobný dôchodok, čiže $9 \%$ z vymeriavacieho základu. Od 1.9.2012 sa tento príspevok znížil na $4 \%$ z vymeriavacieho základu. Podl'a zákona č. 43/2004 Z. z. o starobnom dôchodkovom sporení sa od roku 2017 sadzba poistného zvyšuje každý rok o $0,25 \%$ tak, aby v roku 2024 dosiahla $6 \%$.

Podstatou prvého piliera je previazanost' na ekonomickú aktivitu občanov a ich príjem. Do tohto piliera plynú odvody od všetkých poistencov. V januári 2005 vznikol aj tretí dôchodkový pilier ktorý je dobrovol'ný. Jedná sa o formu dobrovol'ného sporenia z čistej mzdy. Podl'a svojho rozhodnutia občan odvádza zo mzdy istú čiastku. Obvykle rovnakou mierou prispieva aj zamestnávatel'. Výška odvodov na starobné poistenie do Sociálnej poist'ovne je $18 \%$ z vymeriavacieho základu. Následne, ak je občan sporitel’om aj v II. pilieri, Sociálna poist'ovňa vypočítava a postupuje povinné príspevky na starobné dôchodkové sporenie na individuálne účty sporitel'ov vedené v rámci príslušných fondov v DSS.

Do 1. januára 2017 bol vek odchodu do dôchodku zákonom stanovený na 62 rokov u mužov aj žien. Zmenil sa aj spôsob určovania dôchodkového veku. Dôchodkový vek poistencov narodených po 31. decembri 1954 sa v jednotlivých kalendárnych rokoch predíži o počet dní, ktorý stanoví každoročne Ministerstvo práce, sociálnych vecí a rodiny Slovenskej republiky v závislosti od dynamiky vývinu priemernej strednej dížky života spoločnej pre mužov a ženy zistenej Štatistickým úradom Slovenskej republiky. Pre rok 2017 sa dôchodkový vek zvýšil o 76 dní. Opatrením Ministerstva práce, sociálnych vecí a rodiny Slovenskej republiky z 19. septembra 2017 sa dôchodkový vek pre rok 2018 upravil na 62 rokov a 139 dní.

\section{Pol'sko}

Reforma Pol'ského dôchodkového systému, ktorá bola pripravovaná od roku 1997 a plne implementovaná v roku 1999, priniesla zavedenie osobných dôchodkových účtov obyvatel'stva. Okrem dovtedajšieho PAYG systému vznikol povinný II. pilier a dobrovol'ný III. pilier dôchodkového sporenia (Witkowska 2017, Naczyk 2016). Povinne odvádzané príspevky do dôchodkového systému boli rozdelené medzi jeho I. a II. pilier. Výška príspevku do II. kapitalizačného piliera bola pôvodne $7,3 \%$ z hrubej mzdy. Reakciou vlády na finančnú krízu a potrebu zníženia štátneho deficitu bola výška príspevkov v roku 2011 znížená na 3,5 \% a v roku 2013 na 2,92 \% z hrubej mzdy (Zabkowicz, 2016).

II. pilier dôchodkového systému bol výrazne ovplyvnený legislatívnymi zmenami prebiehajúcimi v roku 2014. Všetok majetok v II. pilieri investovaný do štátnych dlhopisov, čo predstavovalo 51,5\% alokovaných aktív sporitel'ov, bol presunutý do I. piliera. Dalšsie investovanie prostriedkov v II. pilieri do pol'ských 
štátnych dlhopisov už nie je možné. Povinnost' účasti v II. pilieri bola zrušená, pre sporitel'ov sa tak stal dobrovolným (Zabkowicz 2016, Marcinkiewicz 2016). Podl'a údajov uverejňovaných Pol'ským orgánom finančného dohl'adu (KNF) nenastala vel'ká zmena počtu evidovaných sporitel'ov, výrazne sa však znížil počet aktívne prispievajúcich sporitel'ov. Medzi mesiacmi júl a august 2014 klesol počet postúpených príspevkov o 11 miliónov, čo predstavovalo viac ako 694 miliónov ZL. Súčasne bola zavedená povinnost' správcovských spoločností dôchodkových fondov postupne mesačne prevádzat' úspory sporitel'ov, ktorým do dôchodkového veku zostáva 10 a menej rokov, do štátneho systému (Zabkowicz, 2016).

\section{Česká republika}

Penzijný systém Českej republiky pozostáva z 2 pilierov - I. piliera priebežného PAYG systému a III. piliera dobrovol'ného dôchodkového sporenia. III. pilier vznikol reformou v roku 1994 a predstavuje dôchodkové pripoistenie so štátnym príspevkom. Podl'a údajov Asociácie penzijných spoločností ČR (APS ČR) využívalo možnost' dobrovol'ného dôchodkového sporenia k 31.12.2017 takmer 4,5 milióna sporitel'ov. To predstavuje $85 \%$ ekonomicky aktívneho obyvatel'stva vo veku 20 - 64 rokov. II. kapitalizačný pilier dôchodkového sporenia bol v Českej republike zavedený zákonom z roku 2011, ako v poslednej z krajín Vyšehradskej štvorky. Vstup do novovzniknutého systému bol pre obyvatel'ov dobrovol'ný. Príspevky na dôchodkové poistenie pozostávali z $3 \%$ hrubej mzdy, ktoré boli odklonené z celkových príspevkov na sociálne zabezpečenie a z $2 \%$ hrubej mzdy, ktoré si každý účastník hradil sám. O legislatívnych zmenách systému dôchodkového zabezpečenia mali politické subjekty rôzne predstavy a reforma si nezískala ani dôveru verejnosti, čo sa prejavilo na nízkej miere účasti ekonomicky aktívneho obyvatel'stva na sporení v II. pilieri. Počet sporitel'ov k 31.12.2013 bol podl'a údajov APS ČR 81 962, teda len 1,6 \% ekonomicky aktívneho obyvatel'stva vo veku 20 - 64 rokov. II. pilier dôchodkové sporenia fungoval len v krátkom období a bol uzatvorený v roku 2015. Novelou zákona o dôchodkovom sporení bola v júli 2015 ukončená možnost' vstúpit' do II. piliera, ktorý bol následne zákonom o ukončení dôchodkového sporenia úplne zrušený (Vopátek, 2017, Árendáš, 2017, Marcinkiewicz, 2016).

\section{Mad'arsko}

V Mad'arsku boli v roku 1993 zavedené dobrovol'né dôchodkové fondy ako doplnok k priebežnému PAYG systému. Povinný II. pilier dôchodkového sporenia bol zavedený v rokoch 1997 - 1998. Smerovala doň čast' príspevkov zamestnancov, pričom príspevky zamestnávatel'ov boli v plnej výške postúpené do štátneho priebežného systému sociálneho zabezpečenia. Pôvodná reforma z roku 1997 stanovila postupné zvyšovanie príspevkov do výšky 8 \% z hrubej 
mzdy. Po nástupe novej vlády v roku 1998 bola výška týchto príspevkov upravená na $6 \%$ z hrubej mzdy. Zvýšsenie príspevkov nastalo v roku 2003 na úroveň $7 \%$ a v roku 2004 na $8 \%$ (Hirose, 2011, Naczyk, 2016). Účast' v II. pilieri dôchodkového sporenia bola povinná pre všetkých nových zamestnancov vstupujúcich na trh práce. Pre starších zamestnancov, už poistených v štátnom dôchodkovom systéme, bol vstup do II. piliera dobrovolný, avšak vstupom sa ich starobný dôchodok vyplácaný z priebežného systému znížil o $25 \%$. Napriek tomu túto možnost' využilo viac ako 2 milióny zamestnancov (Hirose, 2011, Szikra, 2014). Podl'a údajov Mad'arskej centrálnej banky (MNB) bol počet sporitelov v dôchodkových fondov k 31.12.1998 takmer 13,4 milióna, teda 34 \% ekonomicky aktívneho obyvatel'stva vo veku 20 - 64 rokov.

Významné legislatívne zmeny dôchodkového systému a čiastočná likvidácia II. piliera prebiehali počas roka 2010 ako súčast' snahy mad’arskej vlády o zníženie štátneho dlhu. Zrušila sa povinnost' účasti v II. pilieri a existujúcim sporitel'om bolo umožnené vrátit' sa len do štátneho priebežného systému. V decembri 2010 bolo zrušené právo sporitel'ov v súkromných dôchodkových fondoch poberat' starobný dôchodok súčasne aj zo štátneho priebežného systému. Výsledkom týchto zmien bol prechod 97 \% sporitel'ov do priebežného I. piliera. Súčasne boli príspevky do súkromných dôchodkových fondov za 14 mesiacov (od novembra 2010 do decembra 2011) postúpené do I. piliera. (Szikra 2014, Stepan 2014). Szikra (2014) uvádza, že na základe vládneho nariadenia č. 87/2011 boli príspevky súčasných sporitel'ov a prostriedky naakumulované bývalými sporitel'mi presunuté do novovzniknutého Fondu pre dôchodkovú reformu a zníženie deficitu. Legislatívne zmeny $\mathrm{z}$ roku 2007 umožnili existenciu zamestnaneckých dôchodkových fondov, ktoré sú založené na príkladoch z iných Európskych krajín. Zamestnanecký dôchodkový fond je však poskytovaný len jedným správcom a to od roku 2011 (Panduricz, 2017).

\section{Ciele a metódy}

Ciel'om článku je analýza kvantitatívnych ukazovatel'ov kapitalizačných pilierov dôchodkových systémov krajín V4. Analýzu sme vykonali na základe štatistických dát o dôchodkových fondoch II. piliera dôchodkového sporenia týchto krajín. Štatistické dáta boli získané zo Slovenskej národnej banky (NBS), Sociálnej poist'ovne SR (SP SR), Asociácie penzijných spoločností ČR (APS ČR), Pol'ského orgánu finančného dohl'adu (KNF), Mad’arskej centrálnej banky (MNB) a databázy Eurostat.

\section{Výsledky}

Miera zapojenia ekonomicky aktívneho obyvatel'stva do sporenia prostredníctvom dôchodkových fondov II. piliera je znázornená na grafe 2 . 
Na grafe sú znázornené percentuálne podiely počtu evidovaných sporitel'ov a ekonomicky aktívneho obyvatel'stva vo veku od 20 do 64 rokov pre jednotlivé krajiny V4. Miera zapojenia je sledovaná od obdobia vzniku II. piliera v danej krajine do 31.12.2017 (pre Českú republiku do konca roka 2016, kedy bol II. pilier zrušený).

Graf 2: Miera zapojenia obyvatel'stva do II. piliera

Graph 2: The rate of population participation in the second pillar

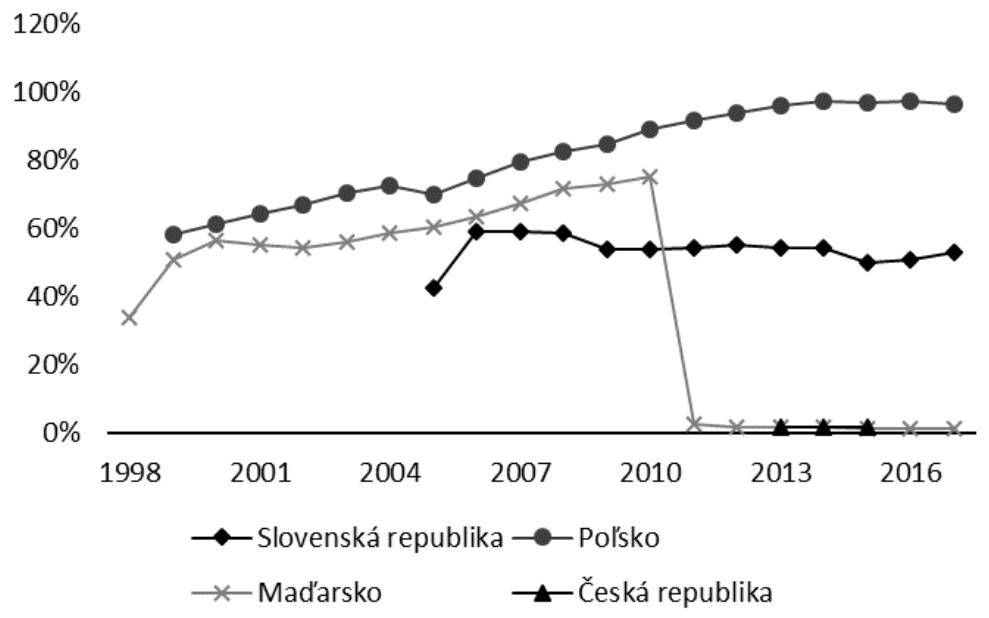

Zdroj: vlastné spracovanie na základe údajov NBS, APS ČR, KNF, MNB a Eurostat

Z grafu 2 je zrejmá najvyššia miera zapojenia do II. piliera v Pol’sku. Tento údaj je však skreslený použitím počtu evidovaných sporitel'ov, nie počtu aktívne prispievajúcich sporitel'ov, ktorý nie je dostupný. V Pol'sku došlo práve $\mathrm{v}$ roku 2014 k výraznému poklesu prispievatel'ov, čo spôsobili legislatívne zmeny dôchodkového systému. Výrazný pokles počtu sporitel'ov je viditel'ný v Mad'arsku v roku 2010, kedy z II. piliera vystúpilo takmer 97 \% účastníkov,

$\mathrm{Na}$ grafe 3 je znázornený vývoj percentuálneho podielu výšky príspevkov postúpených do dôchodkových fondov II. piliera k HDP jednotlivých krajín. Výšku príspevkov sme pre Slovenskú republiku a Mad'arsko sledovali od vzniku II. piliera, pre Pol'sko sú dostupné dáta od roku 2003. Koniec sledovaného obdobia je 31.1.2017. Pre Českú republiku nie sú údaje o výške zaplatených príspevkov do dôchodkových fondov dostupné.

$\mathrm{Na}$ grafe 3 vidíme ako sa prejavovali reformy dôchodkových systémov jednotlivých krajín na výške postúpených príspevkov do dôchodkových fondov. Pri Slovenskej republike je medzi rokmi 2012 a 2013 viditel'ný pokles spôsobený 
znížením výšky odvodov do II. piliera. Napriek tomu vykazuje SR od roku 2013 najvyšší pomer výšky príspevkov k HDP spomedzi sledovaných krajín. V prípade Pol'ska je viditel'ný pokles po roku 2011, kedy sa prejavilo zníženie výšky príspevkov a následne po roku 2014, kedy sa zrušila povinnost' účasti v II. pilieri. Najvýraznejší je pokles v Mad'arsku medzi rokmi 2010 a 2011, kedy prebiehala čiastočná likvidácia II. piliera.

Graf 3: Podiel príspevkov do II. piliera k HDP

Graph 3: The contributions to the second pillar as a share of GDP

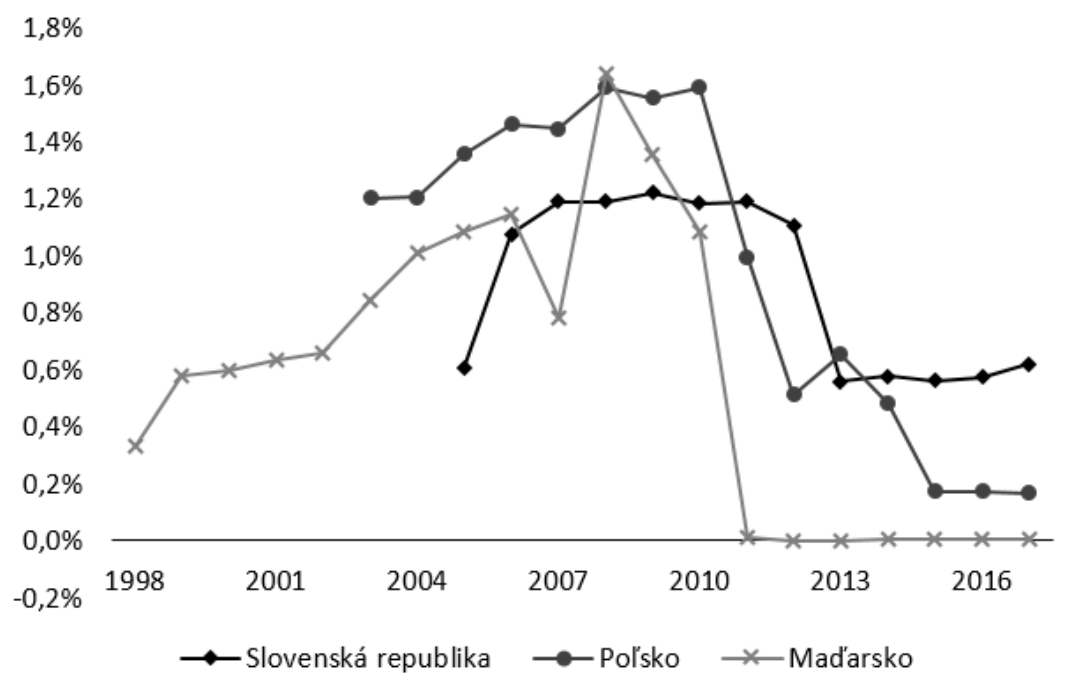

Zdroj: vlastné spracovanie na základe údajov SP SR, KNF, MNB a Eurostat

Pri kapitalizačnom pilieri dôchodkového systému je dôležitá čistá hodnota aktív dôchodkových fondov. Práve z úspor alokovaných počas sporiacej fázy sú jednotlivým účastníkom poskytované dôchodkové dávky vo výplatnej fáze. Na grafe 4 je znázornený percentuálny podiel čistej hodnoty aktív dôchodkových fondov (NAV) k HDP jednotlivých krajín.

$\mathrm{Na}$ NAV dôchodkových fondov vplýva výška príspevkov sporitel'ov a schopnost' fondu tieto prostriedky zhodnotit'. Z grafu 4 je zrejmé, že NAV dôchodkových fondov má prirodzene rastúci charakter. $\mathrm{V}$ prípade Pol'ska sa na jeho výške výrazne prejavili legislatívne zmeny dôchodkového systému v roku 2014, kedy bolo takmer 51,5 percenta aktív presunutých do štátneho I. piliera. V Mad'arsku sa presun aktív z II. kapitalizačného piliera do štátneho I. piliera odohral na základe legislatívnych zmien v roku 2010, kedy je na grafe zrejmý výrazný pokles NAV. 
Graf 4: Podiel NAV dôchodkových fondov k HDP

Graph 4: The NAV of pension funds as a share of GDP

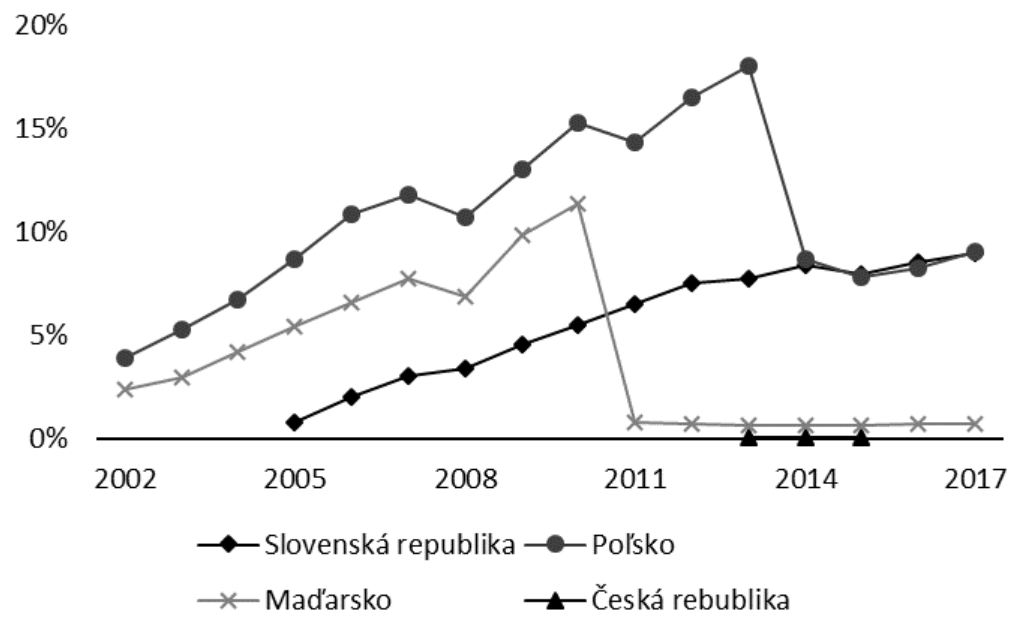

Zdroj: vlastné spracovanie na základe údajov NBS, APS ČR, KNF, MNB a Eurostat.

\section{Záver}

Na fungovanie dôchodkových systémov z hl'adiska finančnej udržatel'nosti i nastavenia systému výrazne vplýva demografický vývoj, fungovanie a vývoj finančných trhov a tiež vývoj na trhu práce. Hladat' optimálny model dôchodkového systému, ktorý by garantoval slušnú životnú úroveň v starobe a zároveň by bol dlhodobo udržatel'ný vzhl'adom na uvedené riziká je vel'mi dôležité. Svetová banka navrhla diverzifikovat' dôchodkový systém ako kombináciu štátnych prvkov na udržanie minimálnych štandardov a prvkov založených na súkromnom financovaní a správe finančných prostriedkov.

V krajinách V4 sú reformy vyvolané politickými a ekonomickými zmenami, a preto majú odlišný charakter ako v pôvodných štátoch EÚ. V krajinách V4 znamená reformný proces úplnú zmenu dôchodkového systému, kým vo vyspelých štátoch EU sú prijímané iba čiastočné zmeny (napr. zvýšenie veku odchodu do dôchodku) ale podstata systému zostáva zachovaná.

Prístup $\mathrm{k}$ dôchodkovej reforme sa $\mathrm{v}$ jednotlivých krajinách V4 odlišuje, kladie rôzne vel'ký dôraz na rôzne parametre systému podl'a tradícií a ekonomických možností. Zvýšené náklady dôchodkových systémov jednotlivé krajiny realizujú $\mathrm{v}$ rámci prvého piliera (štátneho, verejného) alebo tiež prostredníctvom druhého, prípadne tretieho kapitalizačného piliera. Ciel'om reformy v Slovenskej republike bolo zastavenie dlhu priebežne financovaného 
dôchodkového systému generovaného demografickým vývojom a zvýšenie angažovanosti občanov na svojej životnej úrovni v dôchodkovom veku. Toto kladie dôraz na pripravenost' jednotlivcov realizovat' finančné rozhodnutia, ktorých dosah na ich životnú úroveň sa prejaví v období poberania starobného dôchodku. $\mathrm{Na}$ základe kvantitatívnych metód sme analyzovali kapitalizačné piliere dôchodkového poistenia krajín V4. Môžeme konštatovat', že v SR sa do druhého kapitalizačného piliera zapojilo až $53 \%$ z celkového počtu poistencov. V Českej republike je skúsenost' so záujmom o vstup do druhého piliera odlišná. Celkovo doň vstúpilo iba 84000 občanov a v roku 2015 došlo v ČR k zrušeniu druhého piliera. V SR sa druhý pilier otváral v roku 2015 už po štvrtý krát, celkový počet sporitel'ov to ale nijako neovplyvnilo. K dôchodkovej reforme došlo v roku 1998 aj v Mad'arsku a Pol'sku. Do kapitalizačného piliera sa zapojilo v Mad'arsku $34 \%$ poistencov, do revízie reformy v roku 2010 ich počet stúpol na $75 \%$ a v roku 2011 po zásahu vlády klesol počet poistencov na $2,4 \%$. V Pol'sku je do kapitalizačného piliera aktuálne zapojených až $96 \%$ poistencov. Rozdiely sú aj v tvorbe úspor medzi jednotlivými krajinami V4. Tvorba prostriedkov je vykazovaná vo vzt’ahu $\mathrm{k}$ HDP, a to v rozpätí od 0,66 \% v Mad'arsku, cez 8,96 \% na Slovensku až po 9,03\% v Pol'sku ku koncu roka 2017. V podmienkach V4 sú piliere dôchodkového systému vystavané podl'a odlišnej metodiky. V ČR dokonca došlo v roku $2015 \mathrm{k}$ úplnému zrušeniu druhého piliera. Tento pilier bol značne oklieštený aj $\mathrm{v}$ Mad’arsku. Priestor pre súkromné úspory sa v súčasných dôchodkových systémoch krajín V4 ponúka spravidla v tret’om dôchodkovom pilieri, kde môžu jednotlivci formou doplnkového dôchodkové sporenia kumulovat' úspory na budúci dôchodok.

\section{Pod'akovanie}

Príspevok bol spracovaný v rámci projektu VEGA č. 1/0618/17 Moderné nástroje na modelovanie a riadenie rizik $v$ životnom poistení.

\section{Literatúra}

ÁRENDÁS̆, P. a kol. 2017. Dôchodkové fondy vo svete a na Slovensku. 1. vyd. Bratislava: Wolters Kluwer s.r.o. 212 s. ISBN 978-80-8168-663-4.

HIROSE, K. 2011. Hungary. In Hirose, K. (ed.). Pension reform in Central and Eastern Europe: in times of crisis, austerity and beyond [online]. 2011. Budapešt': International Labour Organization. pp. 171-198. ISBN 978-92-2125640-3. [cit. 2018-09-24]. Dostupné na internete: <http://www.ilo.org/ wcmsp5/groups/public/---europe/---ro-geneva/---sro-budapest/documents/publi cation/wcms_171551.pdf>.

MARCINKIEWICZ, E. 2016. The changing landscape of voluntary pensions in the CEE region. In Vrankic, I., Tomic, D. (eds.). Economic and Social Development: 13th International Scientific Conference on Economic and Social 
Development. [online], 2016. Barcelona: Varazdin Development and Entrepreneurship Agency. pp. 455-465. ISSN 1849-7535. [cit. 2018-09-25]. Dostupné na internete: <https://www.esd-conference.com/upload/book_of_ proceedings/2016_Book\%20of\%20Proceedings_Barcelona_Online.pdf $>$.

NACZYK, M. - DOMONKOS, S. 2016. The Financial Crisis and Varieties of Pension Privatization Reversals in Eastern Europe. In Governance: An International Journal of Policy, Administration and Institutions. ISSN 14680491, 2016, vol. 29, no. 2, pp. 167-184.

PANDURICS, A. - SZALAI, P. 2017. The Role of the Second and Third Pension Pillar in the Hungarian Pension System. In Public Finance Quarterly. ISSN 2064-8278, 2017, vol. 62, no. 2, pp. 212-231.

RIEVAJOVÁ, E. 2013. Pension System of the Slovak Republic in the Context of Social and Economical Changes. In 8th International Academic Conference [online], 2013. Prague: IISES. p. 368-385. ISBN 978-80-905241-8-7. [cit. 2018-09-27]. Dostupné na internete: <http://www.iises.net/download/Soubory/ soubory-puvodni/naples-CP-2013.pdf>.

STEPAN, M. 2014. Pension Reform in the European Periphery: The Role of EU Reform Advocacy. In Public Administration and Development. ISSN 1099162X, 2014, vol. 34, no. 4, pp. 320-331.

SZIKRA, D. 2014. Democracy and welfare in hard times: The social policy of the Orban Government in Hungary between 2010 and 2014. In Journal of European Social Policy. ISSN 1461-7269, 2014, vol. 24, no. 5, pp. 486-500.

VOPÁTEK, J. 2017. A Microeconomic Analysis of Small Pension Reform in the Czech Republic (the So-Called First Pillar). In Politická Ekonomie. ISSN 23368225, 2017. vol. 65, no. 1, pp. 96-118.

WITKOWSKA, D. - KOMPA, K. 2017. Polish pension market performance in comparison to selected benchmarks. In Economics \& Sociology. ISSN 23063459, 2017. vol. 10, no. 1, pp. 35-47.

ZABKOWICZ, A. 2016. A Paradox of Reforming Pensions in Poland. In Equilibrium. Quarterly Journal of Economics and Economic Policy. ISSN 2353-3293, 2016, vol. 11, no. 3, pp. 585-602.

ZÁKON č. 43/2004 Z. z. o starobnom dôchodkovom sporení v znení neskorších predpisov.

\section{Internetové zdroje:}

https://ec.europa.eu/eurostat/

https://www.apfcr.cz/

https://www.knf.gov.pl/

https://www.mnb.hu/

https://www.nbs.sk/

https://www.socpoist.sk/ 


\section{THE QUANTITATIVE INDICATORS ANALYSIS OF THE SECOND PILLAR OF PENSION SYSTEM IN V4 COUNTRIES}

\section{Summary}

The functioning of pension systems, in terms of financial sustainability and system regulations, is strongly influenced by demographic developments, behavior and development of financial markets, and labor market developments. Approach to pension reform varies among V4 countries. The increased costs of pension systems in individual countries are realized within the first pillar (state, public) or also through the second or third capitalization pillar. The aim of the article is quantitative analysis of pension capitalization pillars in the V4 countries. We can state that the highest level of participation in the capitalization pillar is in Poland and the Slovak Republic. For now the contributions to the second pillar as a share of GDP are the highest among the V4 countries in Slovakia. In the Czech Republic, the capitalization pillar was abolished in 2015, and in Hungary $97 \%$ of the savers return to the public pension scheme due to reform in 2010. There are also differences in allocation of saving among V4 countries. The net asset value of pension funds as a share of GDP is ranging from $0,66 \%$ in Hungary, through $8,96 \%$ in Slovakia to $9,03 \%$ in Poland by the end of 2017.

\section{Doc. RNDr. Marta Urbaníková, CSc.}

Mgr. Michaela Štubňová

Ústav ekonomiky a manažmentu FPV UKF v Nitre

Trieda A. Hlinku 1, 94974 Nitra

E-mail: murbanikova@ukf.sk,mstubnova@ukf.sk 